\title{
IMPLIKASI KINERJA DAN INDEPENDENSI DEWAN DIREKSI TERHADAP KECENDERUNGAN PERUBAHAN STRATEGI PERUSAHAAN
}

\author{
Samin dan Satria Yudhia Wijaya \\ samin58@ymailcom,satria.wijaya@gmail.com \\ Fakultas Ekonomi UPN "Veteran” Jakarta \\ Jl. R.S. Fatmawati Pondok Labu, Jakarta Selatan - 12450
}

\begin{abstract}
This study examined the implications of the firm financial performance and composition of indepedencies the board of directors tendency to change strategy. Firm financial performance parameters used in this research include : total assets, profitability, and leverage, while measuring changes in the company's strategy is the implementation of low cost and differentiation. The sample of this research consisted of 26 companies in the Indonesia Stock Market with the data period 2009-2012. Hypothesis testing techniques using logistic regression. When company suffered in poor performance become possible change of the board of directors. Company will replace the director with independent directors. These changes are believed to change the company's strategy. The result showed a significant relationship between the independence of the board of directors with financial performance ( $(r=0.311, p=0.025)$ that the high performance associated with the independence of the board of directors. Result for logistic regression is that the predictions sign on IND_BOD is appropriate that the presence of independent directors lead chages into a differentiation strategy. However this is not statistically significant.
\end{abstract}

Keywords : Financial Performance, Differentiation, Low Cost, Independent Director

\section{PENDAHULUAN}

Semakin banyak skandal keuangan yang terjadi dalam dunia bisnis selama beberapa tahun belakangan ini. Skandal tersebut dapat terjadi karena semakin ketatnya persaingan sehingga perusahaan sulit untuk mencapai kinerja terbaiknya. Salah satu aspek untuk meningkatkan kinerja perusahaan adalah dengan Tata Kelola perusahaan (Corporate Governance/CG). Aspek ini akan melakukan tata kelola perusahaan yang menjelaskan hubungan antara berbagai partisipan dalam perusahaan yang menentukan arah dan kinerja perusahaan. Isu mengenai CG ini mulai mengemuka, khususnya di Indonesia, setelah Indonesia mengalami beberapa kali krisis yang yang terjadi dalam 15 tahun terakhir (1998 \& 2008). Banyak pihak yang mencoba menganalisis mengapa krisis selalu berulang di Indonesia disebabkan oleh sangat lemahnya CG yang diterapkan dalam perusahaan di Indonesia. Sehingga baik pemerintah maupun investor mulai memberikan perhatian yang cukup signifikan dalam praktek CG.

Salah satu aspek dalam CG adalaha bagaimana independensi 
dewan direksi dalam perusahaan. Sistim organisasi top management di Indonesia telah memisahkan antara dewan direksi dan dewan komisaris komisaris Dewan direksi adalah sebagai pihak yang menjalankan operasional perusahaan, sedangkan dewan komisaris adalah pihak yang mengawasi (termasuk memberi saran/usul) kepada direksi agar operasional perusahaan dapat berjalan sesuai dengan visi dan misi. Peraturan dan perundang-undangan di Indonesia belum mengatur independensi dewan direksi, kecuali bagi perusahaan yang telah mencatatkan sahamnya di Bursa Efek Indonesia (BEI). Paper ini akan menguji dan menunjukkan bagaimana komposisi dewan direksi dalam perusahaan yang cenderung dapat merubah strategi perusahaan. Komposisi dewan direksi, bisa dalam bentuk jumlah direksi yang terlibat dan jenis komposisinya (inside vs outside). Adanya pihak luar (outside) yang merupakan pihak independen diharapkan dapat memberikan kontribusi kepada perusahaan. Pihak independen juga diharapkan mampu untuk melindungi kepentingan pemegang saham dengan membuat keputusan strategis sehingga meningkatkan (Kosnik, 1990).

Beberapa penelitian sebelumnya telah banyak yang menggunakan isu indepedensi dan komposisi dewan direksi sebagai pemicu pengambilan keputusan strategis sehingga meningkatkan kinerja perusahaan. Keberadaan dewan direksi yang independen membawa dampak positif terhadap kinerja perusahaan dimasa mendatang (Pearce \& Zahra, 1992), sedangkan penelitian lain menguji keutamaan dewan direksi independen dalam menetapkan strategi perusahaan pada masa mendatang (Takhasori \& Boulton, 1985).

Penelitian ini akan menguji implikasi hasil kinerja keuangan dan komposisi dewan direksi independen terhadap kecenderungan perubahan strategi perusahaan. Kondisi Indonesia memiliki sedikit perbedaan dalam struktur organisasi top management seperti diungkapkan pada awal pendahuluan. Model analisis penelitian ini akan menggunakan regresi logistic dengan sampel perusahaan public yang terdaftar pada Bursa Efek Indonesia (BEI) periode 2009-2012.

\section{TINJAUAN PUSTAKA DAN PENGEMBANGAN HIPOTESIS Corporate Governance}

Salah satu peran dari dewan direksi perusahaan adalah untuk meminimalkan biaya pengawasan akibat dari adanya pemisahan antara pemilik dan pengendali keputusan dalam perusahaan modern. Dewan Direksi akan menerima pelimpahan wewenang untuk melakukan pengendalian internal dan pengendalian keputusan dari pihak pemegang saham perusahaan. Pendelegasian wewenang ini dikarenakan para pemegang saham mengalihkan resiko yang dihadapinya akibat dari investor yang memiliki saham untuk beberapa perusahaan sekaligus, sedangkan disisi lain pemegang saham menginginkan bahwa manajemen bertindak sesuai dengan kepentingan pemilik.

Berdasarkan UU Perseroan Terbatas No.40 tahun 2007 pasal 120 
ayat 1, maka tidak dikenal istilah dewan direksi independen. UU tersebut hanya mengatur tentang kewajiban perusahaan untuk adanya 1 orang komisaris independen dan 1 orang komisaris utusan. Namun demikian, sesuai dengan Keputusan Direksi Bursa Efek Jakarta (BEJ) No. Kep-305//BEJ/07-2004 tanggal 19 Juli 2004 tentang Peraturan Nomor I-A tentang Pencatatan Saham dan Efek Bersifat Ekuitas Selain Saham yang Diterbitkan oleh Perusahaan Tercatat pada poin III.1.5 dan III.1.6, sebagaimana telah dirubah dengan Surat Keputusan Direksi Bursa Efek Indonesia (BEI) No. Kep00001/BEI/01-2014 bahwa perusahaan tercatat wajib untuk memiliki Direktur Tidak Terafiliasi sekurang-kurangnya 1 orang dari jajaran anggota Direksi dengan periode jabatan maksimal 2 kali.

Komposisi dari dewan direksi adalah salah satu faktor penting yang akan mengefektifkan monitoring terhadap kebijakan manajemen. Kepentingan ini akan dapat efektif jika komposisi dewan direksi adalah berasal dari dalam (manajemen) dan juga dari luar (non manajemen). Komposisi seperti ini diharapkan akan menambah nilai perusahaan. Dimasukkanya dewan direksi yang berasal dari luar perusahaan agar mampu menambah reputasi perusahaan, dimana pihak luar manajemen tentu akan mempertaruhkan nama dan kinerja terbaiknya. Selain itu dengan pengalaman dewan direksi yang non manajemen akan membantu membangun perusahaan dan secara tidak langsung mengawasi operasional perusahaan. Alasan digunakan dewan direksi yang berasal dari non manajemen antara lain (Beasley, 1996) : (1) mereka lebih berpengalaman, (2) mereka paham akan pentingnya pengendalian keputusan, dan (3) mereka bekerja dalam suatu sistem yang terkendali.

Teori yang dikemukakan Fama (1980) dan Fama \& Jensen (1983) berkaitan dengan komposisi dewan direktur adalah semakin tingginya komposisi dewan direksi yang berasal dari non manajemen akan meningkatkan efektifitas dewan dalam melakukan pengendalian operasional manajemen. Semakin efektif pengendalian perusahaan maka keputusan strategi yang diambil akan menguntungkan bagi kinerja perusahaan. Beberapa riset sebelumnya (Shivdasani, 1993) telah mengklasifikasikan dewan direksi yang berasal dari non manajemen sebagai "direksi independen" dan "grey director". Direksi independen adalah direksi yang berasal dari luar perusahaan dan tidak memiliki afiliasi/hubungan dengan perusahaan dan dengan dewan direksi lainnya. Sedangkan grey director adalah direksi yang berasal dari luar perusahaan dan kemungkinan memiliki afiliasi dengan direksi lain dalam perusahaan. Kategori direksi ini ada kemungkinan memunculkan permasalahan akibat adanya hubungan afiliasi dengan manajemen. Fama (1980) dan Fama \& Jensen (1983) memprediksikan bahwa tingginya komposisi dari direksi independen akan meningkatkan efektifitas dewan direksi dalam pengambilan keputusan strategis. 


\section{Independensi}

Salah satu faktor keberhasilan pengelolaan perusahaan adalah adanya adanya salah satu dewan direksi yang independen. Dewan direksi independen adalah anggota dewan direksi yang tidak terafiliasi dengan pemegang saham pengendali, tidak mempunyai hubungan afiliasi dengan komisaris atau direksi lainnya, tidak bekerja rangkap sebagai direksi pada perusahaan lain, dan tidak menjadi orang dalam pada lembaga atau profesi penunjang pasar modal yang jasanya digunakan oleh perusahaan. Independensi berarti sikap mental yang bebas dari pengaruh, tidak dikendalikan oleh orang lain, tidak tergantung pada orang lain. Independensi dapat juga diartikan adanya kejujuran dalam diri seseorang dengan memperhatikan fakta dan pertimbangan obyektif, serta tidak memihak dalam mengambil keputusan (Ningrum 14 Agustus 2014, hlm 1). Adanya dewan direksi yang independen diharapkan dapat mengelola perusahaan secara professional sesuai dengan bidang keahliannya.

\section{Strategi Perusahaan.}

Strategi adalah suatu sarana bagi organisasi untuk mencapai tujuan, karena merupakan sarana maka strategi diharapakan dapat menjawab tantangan dan merebut peluang yang ada melalui persaingan yang semakin kempetitif dimasa yang akan datang dengan berbagai keunggulan yang dimiliki suatu organisasi. Menurut Grant (1999), Meskipun strategi dapat membantu pencapaian suatu keberhasilan, namun strategi tidak menjamin keberhasilan. Ada beberapa faktor yang menunjang tercapainya suatu sukses sebagai berikut : (1) Tujuan yang sederahana, konsisten dan berjangka panjang,

Pemahaman yang baik mengenai lingkungan persaingan, (3) Penilaian yang baik mengenai sumber daya yang dimiliki, dan (4) Pelaksanaan yang efektif. Keselarasan ke empat hal tersebut diatas diharapkan keberhasilan suatu organisasi akan diraihnya sesuai dengan tujuan yang telah ditetapkan serta dapat menyikapi lingkungan persaingan dengar arif dan bijaksana dan mengeksploitasi sumberdaya yang dimiliki oleh organisasi dengan melindungi kelemahan-kelemahan yang ada didalam organisasi.

Salah satu strategi yang dikenal sangat luas strategi generik Porter yang akhir-akhir ini sering digunakan dalam suatu organisasi dalam memenangkan persaingan dalam industri. Ada tiga pendekatan strategi generik yang secara potensial akan berhasil mengungguli perusahaan lain dalam suatu industri, yaitu :
a. Keunggulan biaya menyeluruh (Cost Leadership)

b. Diferensiasi (Differentiatian)

c. Fokus (Focus)

Strategi generik yang pertama yaitu strategi keunggulan biaya menyeluruh adalah mencapai keunggulan biaya menyeluruh dalam industri melalui seperangkat kebijakan fungsional yang ditujukan kepada sasaran pokok. Kedua adalah mendiferensiasikan produk atau jasa yang ditawarkan perusahaan, yaitu menciptakan sesuatu yang baru yang 
dirasakan oleh keseluruhan industri sebagai hal yang unik. Ketiga adalah strategi fokus dibangun untuk melayani target tertentu secara baik, (Porter, 1980).

\section{Kinerja}

Tercapainya tujuan suatu organisasi hanya dimungkinkan karena upaya para pelaku yang ada pada organisasi tersebut. Kinerja merupakan hasil kerja yang dicapai oleh seseorang atau sekelompok dalam suatu organisasi dalam kurun waktu tertentu, sesuai dengan wewenang dan tanggung jawab masing-masing, dalam rangka upaya mencapai tujuan organisasi yang bersangkutan secara legal , tidak melanggar hukum dan sesuai dengan moral maupun etika. Berdasarkan pengertian ini sebenarnya terdapat hubungan yang erat antara kinerja perorangan (individual performance) dengan kinerja lembaga (institusional performance). Dengan perkataan lain bila kinerja perorangan baik maka kemungkinan besar kinerja organisasi juga akan baik.
Kinerja individu akan baik bila dia mempunyai keahlian (skill) yang tinggi, bersedia bekerja karena digaji atau diberi upah sesuai dengan perjanjian, mempunyai harapan (expectation) masa depan yang lebih baik. Perusahaan sebagai organisasi pelayanan masyarakat perlu menunjukkan kinerja sesuai dengan misi yang diembannya, karena kinerja organisasi atau perusahaan adalah hasil dari semua keputusan manajemen yang dilakukan terus-menerus (Helfert, 1991).

\section{Pengembangan Hipotesis Kinerja - Independensi Dewan Direksi - Strategi.}

Pada saat perusahaan mengalami hasil kinerja yang buruk maka ada kemungkinan melakukan pergantian dewan direksi. Perusahaan akan mengganti dewan direksi yang insider dengan outsider (direksi independen). Perubahan ini diyakini akan merubah strategi (Hermalin \& Weisbach, 1988).

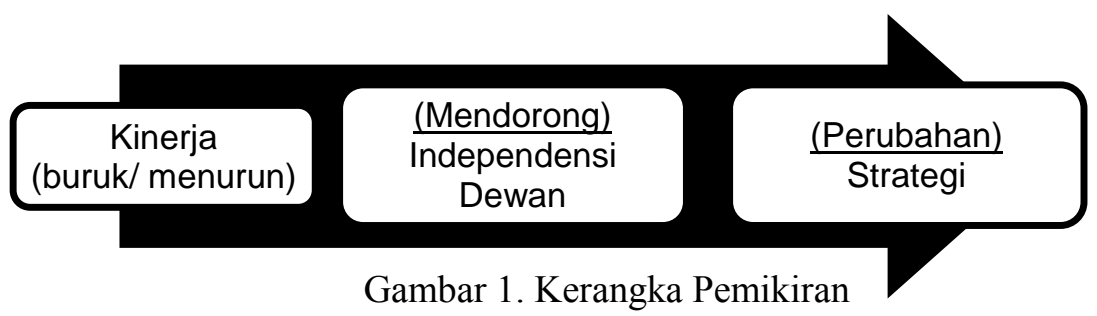

Berdasarkan kerangka pemikiran tersebut maka hipotesis yang dikembangkan dalam penelitian ini adalah:

H1 : Adanya dewan direksi yang independen kemungkinan maka

besar kecenderungan perubahan strategi perusahaan.

H2,3,4 : Semakin rendah kinerja keuangan (Total Aset, ROE, DER) maka kemungkinan besar kecenderungan perubahan strategi perusahaan. 
METODE PENELITIAN

\section{Populasi dan Sampel}

Populasi penelitian ini adalah kategori perusahaan manufaktur dan perdagangan yang terdaftar di Bursa Efek Indonesia (BEI) tahun 20092012. Data keuangan perusahaan didapat dari laporan keuangan yang diserahkan kepada pihak Otoritas Jasa Keuangan (OJK, d/h Badan Pengelola Pasar Modal (BAPEPAM)). Perusahaan terpilih adalah manufacturing, trading, and services firm. Konsentrasi industri yang terpilih dan jumlah perusahaan dapat dilihat pada tabel 1 .

Tabel 1

$\underline{\text { Seleksi Sampel }}$

\begin{tabular}{lr}
\hline Panel A. Populasi dan Sampel & \\
Industri Dasar dan Kimia & 56 \\
Aneka Industri & 41 \\
Industri Barang Konsumsi & 30 \\
Perdagangan Barang Produksi & 26 \\
Retail & 14 \\
Pariwisata & 10 \\
Komputer & 8 \\
Populasi & $\mathbf{1 8 5}$ \\
Data tidak tersedia lengkap & 19 \\
Tidak memenuhi kriteria & 140 \\
Sampel & $\mathbf{2 6}$ \\
Total observasi 2009-2012 & $\mathbf{1 0 4}$
\end{tabular}

Panel B. Kategori Strategi

1. Efisiensi Aset:

Low Cost

Differentiation $\quad 50$

2. Harga Premium

Low Cost 42

Differentiation 62

Sumber : olah data Laporan Keuangan

Pemilihan manufacturing firm karena berdasar pengamatan di BEI bahwa manufacturing, trading, and services firm merupakan industri yang dominan dibanding industri lainnya. Sampel harus memenuhi kriteria utama dalam penelitian ini yaitu memiliki direktur independen / non-afiliasi dengan perusahaan.

\section{Operasionalisasi Variabel}

Bagian ini menjelaskan variabel yang digunakan sebagai proksi pada penelitian, antara lain :

a. $\triangle$ STRA, dengan menggunakan proksi Efisiensi Penggunaan Aset dan Harga Premium

1. Efisiensi Penggunaan Aset yaitu rasio total penjualan dibagi dengan total aset 
2. Harga premium yaitu rasio laba kotor dibagi dengan total penjualan.

Penggunaan 2 proksi tersebut sesuai dengan penelitian terdahulu (Gani \& Jermias, 2006) bahwa pengukuran strategi kompetitif dapat dengan ratio tersebut.

b. Independensi Dewan Direksi (IND_BOD)

Independensi dewan direksi diukur dengan rasio antara direktur independen dengan total seluruh dewan direksi per tanggal 31 Desember. Rasio ini digunakan oleh penelitian sebelumnya untuk mengukur level independensi direksi (Pearce \& Zahra, 1992)

c. Aset (LN_ASET)

Dihitung berdasarkan total aset perusahaan pada tanggal 31 Desember periode 2009- 2012

d. Return on Equity (ROE)

Rasio ini dihitung dengan cara membagi Laba setelah pajak dibagi dengan total ekuitas perusahaan pada tanggal 31 Desember. Rasio ini menunjukkan hasil kinerja perusahaan berdasarkan angka akuntansi yang dilaporkan (accounting based measure).

e. Debt to Equity Ratio (DER)

Rasio ini dihitung dengan cara membagi total kewajiban dengan total ekuitas perusahaan per tanggal 31 Desember. Rasio ini adalah yang paling banyak digunakan dalam penelitian-penelitian sebelumnya. Mather (1998) dalam Gerhardy \& Wyatt (2000) menyatakan bahwa 2 buah leverage ratio yang sering digunakan pihak bank dalam kontrak kredit adalah debt to tangible assets ratio dan debt to equity ratio.

\section{Teknik Pengumpulan Data}

Teknik pengumpulan data yang dilakukan adalah dengan cara sebagai berikut:

a. Jenis Data

Data yang diperlukan untuk mendukung penelitian ini merupakan data sekunder, yaitu data yang diperoleh secara tidak langsung dari sumber utama (perusahaan) yang dijadikan objek penelitiaan. Data tersebut yaitu berupa laporan keuangan perusahaan dari tahun 2009 sampai dengan tahun 2012.

b. Sumber Data

Sumber data yang diperoleh untuk penelitian ini diambil melalui situs homepage Bursa Efek Indonesia (BEI) yaitu www.idx.co.id.

c. Pengumpulan Data

Penelitian ini dilakukan dengan cara membaca dan mempelajari litaratur seperti buku-buku, jurnal, koran, dan berbagai sumber tertulis lainnya yang berkaitan dengan topik penelitian (Penelitian Kepustakaan / Library Research). Data yang digunakan dalam penelitian ini merupakan data sekunder sehingga prosedur pengumpulan data dilakukan dengan teknik observasi terhadap laporan keuangan yang telah dipublikasikan oleh perusahaan yang diambil sebagai sampel dalam penelitian ini melalui website Bursa Efek Indonesia. 


\section{Tehnik Analisis dan Uji Hipotesis}

Metode analisis yang digunakan dalam penelitian ini adalah statistic deskriptif dan uji hipotesis menggunakan regresi logistik. Statistik deskriptif menyajikan gambaran data atas variable-variabel dalam penelitian, sedangkan regresi logistik akan menguji seberapa besar pengaruh variable independent terhadap kemungkinan perubahan variable dependen. Menurut Ghozali (2011:333) dalam tehnik analisis regresi logistic tidak memerlukan uji normalitas pada variable bebasnya. Berikut adalah tahapan dalam regresi logistik yang perlu dilakukan, yaitu :

\section{a. Uji Multikolinieritas}

Uji ini bertujuan untuk menguji apakah pada model regresi ditemukan adanya korelasi antar variable independen. Model yang baik adalah regresi dengan tidak adanya gejala korelasi yang kuat diantara variable independen. Jika variable independen saling berkorelasi, maka variable-variabel ini tidak ortogonal. Variabel ortogonal adalah variable independen yang nilai korelasi antar sesama variable independen sama dengan nol (Ghozali, 2011:105).

b. Menilai Kelayakan Model Regresi Penilaian kelayakan model regresi dinilai menggunakan Hosmer and Lemeshow's Goodness of Fit Test. Pengujian ini akan menguji hipotesis nol bahwa data empiric cocok atau sesuai dengan model (tidak ada perbedaan antara model dengan data sehingga model dapat dikatakan fit). Jika nilai statistic Hosmer and Lemeshow's Goodness of Fit Test sama dengan atau kurang dari 0,05 maka hipotesis nol ditolak yang berarti ada perbedaan signifikan antara model dengan nilai observasinya sehingga Goodness of Fit model tidak baik karena model tidak dapat memprediksi nilai observasinya.Sebaliknya, jika nilai Hosmer and Lemeshow's Goodness of Fit Test lebih besar dari 0,05 maka hipotesis nol tidak dapat ditolak dan berarti model mampu memprediksi nilai observasinya atau dapat dikatakan model dapat diterima karena cocok dengan data observasinya. Hosmer and Lemeshow's Goodness of Fit Test diukur dengan nilai Chi-Square (Ghozali, 2011:341)

\section{c. Menilai Keseluruhan Model (Overall Model Fit Test)}

Langkah pertama adalah menilai keseluruhan model data. Beberapa tes statistic diberikan untuk menilai hal ini. Hipotesis untuk menilai model fit ini adalah :

H0: model yang dihipotesiskan fit dengan data

Ha: model yang dihipotesiskan tidak fit dengan data

Berdasarkan hipotesis tersebut jelas terlihat bahwa hipotesis nol tidak akan ditolak agar model fit dengan data. Statistik yang digunakan berdasarkan pada fungsi likelihood. Likelihood L dari model adalah probabilitas bahwa model yang dihipotesiskan menggambarkan data input. Untuk menguji hipotesis nol dan alternative, maka $\mathrm{L}$ ditransformasikan menjadi -2Log L. Penurunan Likelihood (-2LL) menunjukkan model regresi yang lebih baik atau dengan kata lain 
model yang dihipotesiskan fit dengan data (Ghozali, 2011:340)

\section{d. Koefisien Determinasi} (Nagelkerke R Square)

Cox dan Snell's $R$ Square merupakan ukuran yang mencoba meniru ukuran R2 pada multiple regression yang didasarkan pada tehnik estimasi likelihood dengan nilai maksimum kurang dari 1 (satu), sehingga sulit diinterpretasikan. Nagelkerke $R$ Square merupakan modifikasi dari koefisien Cox dan Snell untuk memastikan bahwa nilainya bervariasi dari 0 (nol) sampai 1 (satu). Hal ini dilakukan dengan cara membagi nilai Cox dan Snell's dengan nilai maksimumnya. Nilai Nagelkerke $R$ Square yang kecil berarti kemampuan variablevariabel independen dalam menjelaskan variasi variable dependen sangat terbatas. Nilai yang mendekati 1 (satu) berarti variable-variabel independen memberikan hampir semua informasi yang dibutuhkan untuk memprediksi variabilitas variable dependen (Ghozali, 2011:341)

e. Pengujian Simultan (Omnibus Test of Model Coefficient)

Pengujian ini dilakukan untuk menguji apakah variable-variabel independen secara bersama-sama (simultan) berpengaruh terhadap variable dependen.

\section{f. Pengujian Parsial (Wald Test)}

Uji statistic parsial (uji t) pada dasarnya menunjukkan seberapa jauh pengaruh satu variable independen secara individual dalam menerangkan variasi variable dependen. Pengujian hipotesis dilakukan dengan cara membandingkan antara nilai probabilitas (sig) dengan tingkat signifikansi. Uji hipotesis yang digunakan adalah :

1. H0 diterima apabila statistic Wald hitung lebih kecil $(<)$ Chi-Square table dan nilai probabilitas (sig) lebih besar $(>)$ tingkat signifikansi. Hal ini berarti $\mathrm{Ha}$ ditolak atau hipotesis yang menyatakan variable independen berpengaruh terhadap variable dependen ditolak.

2. H0 ditolak apabila statistic Wald hitung lebih besar $(>)$ Chi-Square table dan nilai probabilitas (sig) lebih kecil $(<)$ tingkat signifikansi. Hal ini berarti $\mathrm{Ha}$ diterima atau hipotesis yang menyatakan variable independen berpengaruh terhadap variable dependen diterima.

\section{g. Model Regresi Logistik}

Paper ini menggunakan model logit untuk menguji hipotesa yang diajukan, karena variabel dependent adalah variabel kategorikal/dikotomi yaitu 1 (jika perusahaan melakukan perubahan strategi), dan 0 (jika lainnya/tidak mengubah strategi). Model logit ini banyak digunakan dalam penelitian-penelitian mengenai pengujian pemilihan kebijakan akuntansi (Johnson \& Ramanan, 1988; Wong, 1988a; Wong, 1988b; Francis, 1987; Ayres, 1986 dalam Stone \& Rasp, 1991). Topik-topik mengenai prediction atau pengambilan keputusan juga relevan menggunakan model logit. 
Berdasarkan perumusan hipotesa maka model logit yang akan diprediksi adalah :

$\operatorname{Ln}\left(\frac{p_{i t}}{1-p_{i t}}\right)=\alpha_{0}+\alpha_{1} I N D_{-} B O D_{i t}+\alpha_{2} L_{n} A S E T_{i t}+\alpha_{3} R O E_{i t}+\alpha_{4} D E R_{i t}+\varepsilon$

Keterangan:

$\mathrm{p}_{\text {it }}$

: probabilita perusahaan i dalam merubah strategi di tahun $\mathrm{t}$

$\mathrm{IND}_{\mathrm{BOOD}}$ : independensi dewan direksi perusahaan i di tahun $\mathrm{t}$

LN_ASET $_{i t}$ : aset perusahaan i di tahun $\mathrm{t}$

$\mathrm{ROE}_{\text {it }} \quad$ : Return on Equity perusahaan i di tahun $\mathrm{t}$

$\mathrm{DER}_{\text {it }}$ : debt to equity ratio perusahaan i di tahun $\mathrm{t}$

\section{HASIL DAN PEMBAHASAN Deskripsi Objek Penelitian}

Objek penelitian yang digunakan dalam penelitian ini adalah perusahaanperusahaan yang tergolong dalam kelompok / sektor manufaktur, perdagangan, dan jasa yang terdaftar di Bursa Efek Indonesia (BEI) selama empat periode yaitu dari tahun 2009 sampai 2012, dan dipilih berdasarkan kriteria yang telah ditetapkan dengan menggunakan metode purposive sampling. Perusahaan dalam kelompok/sektor tersebut dipilih karena : (1) kelompok yang mendominasi sebagian perusahaan yang tercatat di BEI, sehingga hasil penelitian ini diharapkan dapat diterapkan untuk semua perusahaan, (2) sector terpilih adalah industry dengan produk inovasi yang tinggi sehingga dinamis mengikuti perkembangan global.
Berdasarkan table 1, maka total sampel pada periode observasi tahun 2009-2012 adalah berjumlah 104 . Terlihat pada panel B table 1 bahwa terdapat 54 data perusahaan memilih strategi efisiensi asset berupa low cost dan 50 data perusahaan memilih strategi efisiensi asset berupa differentiation. Hasil tersebut menggambarkan bahwa dalam hal efisiensi asset maka jumlah perusahaan yang memilih antara low cost dan differentiation adalah cukup berimbang. Perusahaan yang menggunakan low cost maupun differentiation senantiasa akan efisiensi dalam menggunakan asset. Penggunaan asset selalu dioptimalkan oleh perusahaan untuk mencapai tujuan maksimalisasi laba sehingga apapun strategi yang dipilih tetap mengedepankan efisiensi penggunaan asset.

Untuk strategi harga premium, maka terdapat 42 data perusahaan yang memilih strategi low cost dan 62 data perusahaan memilih strategi differentiation. Produk yang dihasilkan dari strategi differentiation adalah produk yang unik dan berbeda. Perusahaan dengan strategi ini cenderung akan menetapkan harga yang lebih tinggi atas produk yang dihasilkan. Persaingan usaha yang cukup ketat menyebabkan banyak perusahaan memilih strategi differentiation walaupun untuk hal tersebut harus menetapkan harga premium.

\section{Statistik Deskriptif dan Korelasi Antar Variabel.}

Pada tabel 2 berikut ditunjukkan hasil dari statistik deskripti untuk perusahaan sampel. Berdasarkan tabel 
terlihat bahwa rata-rata perusahaan memiliki direksi independent sebanyak $23 \%$, dengan nilai tertinggi komposisi direksi independen adalah 50\%. Walaupun kecenderungan perusahaan memiliki direksi independen tetapi terdapat nilai minimum 0 , yaitu satu saat dimana perusahaan belum memasukkan unsur independensi pada komposisi dewan direksinya. Rata-rata perubahan strategi efisiensi penggunaan aset adalah $-49 \%$, yang berarti bahwa perusahaan melakukan perubahan strategi dari low cost menjadi differentiation strategi pada periode ini. Sedangkan rata-rata perubahan strategi harga premium adalah $8 \%$, bahwa perusahaan memang cenderung untuk melakukan strategi differentiation walaupun perubahan ini hanya sebagian kecil.

Tabel 2

Deskriptif Statistik

\begin{tabular}{|l|c|c|c|c|c|c|}
\hline & IND_BOD & TOTAL ASET $^{*}$ & \multicolumn{1}{|c|}{$\Delta$ STRAEFI } & $\Delta$ STRAPREM & ROE & DER \\
\hline Mean & 0,23 & 1.891 .738 & $-0,49$ & 0,08 & 0,13 & 1,30 \\
\hline St. Dev & 0,13 & 2.158 .274 & 2,58 & 0,51 & 0,20 & 1,42 \\
\hline Median & 0,20 & 1.040 .218 & $-0,01$ & 0,01 & 0,13 & 0,98 \\
\hline Minimum & 0,00 & 22.043 & $-15,07$ & $-0,74$ & $-0,34$ & $-1,62$ \\
\hline Maksimum & 0,50 & 10.371 .567 & 1,75 & 3,38 & 0,70 & 6,35 \\
\hline
\end{tabular}

*juta Rp.

Sumber : olah data SPSS

Pada tabel 3 berikut melakukan rekrut direksi yang tidak ditunjukkan korelasi antar variabel. Hasil signifikan adalah untuk hubungan antara independensi dewan direksi dengan total aset $(\mathrm{r}=0,368, \mathrm{p}$ $=0,007)$ yang menunjukkan bahwa semakin besar perusahaan maka semakin tinggi tingkat independensi dewan direksi dengan cara adanya independensi dewan direksi. terafiliasi dengan perusahaan untuk membantu melindungi kepentingan pemegang saham. Hubungan yang signifikan juga antara independensi dewan direksi dengan kinerja ROE ( $\mathrm{r}$ $=0,311, \mathrm{p}=0,025)$ bahwa kinerja yang tinggi berhubungan dengan Tabel 3

Pearson Correlation

\begin{tabular}{|c|c|c|c|c|c|c|}
\hline Variabel & IND_BOD & LN_ASET & EFI & PREM & ROE & DER \\
\hline IND_BOD & 1 & & & & & \\
\hline \multirow[t]{2}{*}{ LN_ASET } & $.368^{* *}$ & 1 & & & & \\
\hline & .007 & & & & & \\
\hline \multirow[t]{2}{*}{ EFI } & .218 & .195 & 1 & & & \\
\hline & .120 & .165 & & & & \\
\hline \multirow[t]{2}{*}{ PREM } & .183 & -.197 & -.033 & 1 & & \\
\hline & .194 & .161 & .816 & & & \\
\hline \multirow[t]{2}{*}{ ROE } & $.311^{*}$ & .173 & .019 & -.150 & 1 & \\
\hline & .025 & .219 & .895 & .287 & & \\
\hline \multirow[t]{2}{*}{ DER } & -.087 & .256 & .111 & -.012 & $.519^{* *}$ & 1 \\
\hline & .538 & .067 & .435 & .935 & .000 & \\
\hline
\end{tabular}

Sumber : olah data SPSS 


\section{Pengujian hipotesis.}

Tabel 4 berikut adalah hasil regresi logistik untuk strategi efisiensi aset dan harga premium sebagai variabel independen yang merupakan kategorikal 1 jika perusahaan melakukan perubahan strategi dan 0 jika tidak.

\section{Strategi efisiensi penggunaan aset.}

Tabel uji signifikansi terhadap intersep dengan uji Wald menunjukkan hasilnya signifikan secara statistik pada $\alpha=5 \%$. Nilai $\mathrm{R}^{2}$ memberikan arti bahwa $4 \%$ perubahan strategi dapat dijelaskan oleh variabelvariabel independent (Independensi direksi, Aset, ROE, DER). Berdasarkan uji $\mathrm{G}$, diperoleh nilai 2log likelihood sebesar 69,65. Dengan angka yang sebesar itu, maka dapat disimpulkan bahwa semua variabel dapat dimasukkan ke dalam model, artinya secara bersama-sama variabel independen mempengaruhi variabel dependen (Nachrowi dan Usman, 2002)
Nilai intersep dari model yang dihasilkan adalah 8,33 (sig $=0,16)$ yang berarti bahwa hasilnya tidak signifikan, berarti $\ln \left(\frac{p}{1-p}\right)=8,33$ pada saat semua variable berharga 0 . Dengan demikian probabilitas bahwa suatu perusahaan akan merubah strategi menjadi differentiation adalah $p=\frac{e^{8,33}}{1+e^{8,33}}=0,99 \quad$ atau 99\%. Prediksi tanda pada IND_BOD adalah sesuai dengan prediksi bahwa keberadaan direksi independen menyebabkan perubahan strategi menjadi differentiation. Namun hal ini tidak signifikan secara statistik.

\section{Strategi efisiensi harga premium.}

Hasil yang tidak jauh berbeda juga didapatkan untuk harga premium sebagai variabel independen. Terjadi kenaikan nilai $\mathrm{R}^{2}$, yang memberikan arti bahwa $12,3 \%$ perubahan strategi dapat dijelaskan oleh variabel-variabel independent (Independensi direksi, Aset, ROE, DER).

Tabel 4

Hasil Pengujian Regresi Logistik

\begin{tabular}{lccccc}
\hline \multirow{2}{*}{ Variabel } & \multirow{2}{*}{ Prediksi Tanda } & \multicolumn{4}{c}{ Strategi Kompetisi } \\
\cline { 3 - 6 } & & \multicolumn{2}{c}{ Efisiensi } & Aset & Harga Premium \\
\cline { 3 - 6 } & & koefisien & Sig & koefisien & Sig \\
\hline Intersep & - & 8,33 & 0,16 & $-5,48$ & 0,43 \\
IND_BOD & $-2,66$ & 0,32 & 5,38 & 0,08 \\
LN_ASET & + & $-0,28$ & 0,16 & 0,14 & 0,55 \\
ROE & - & $-0,66$ & 0,71 & $-2,13$ & 0,26 \\
DER & + & 0,085 & 0,72 & 0,13 & 0,59 \\
Uji Wald & & 0,077 & $0,023 *$ & 1,899 & 0,168 \\
-2 Log Likelihood & & 69,652 & & 63,311 & \\
Cox\&Snell R Square & & 0,044 & & 0,123 \\
\hline *sig pada $\alpha=5 \%$ & & & \multicolumn{4}{c}{} \\
\hline
\end{tabular}

Sumber : olah data SPSS 
Keterbatasan Penelitian

Penelitian ini masih memiliki beberapa keterbatasan, sebagai berikut:

a. Jumlah perusahaan yang menjadi sampel hanya 26 dari total populasi sebanyak 185 . Walaupun penelitian ini mengambil sampel 3 kategori / sector dengan populasi paling banyak (manukatur, perdagangan, dan jasa) namun ternyata sampel yang memenuhi kriteria hanya $14 \%$ saja.

b. Banyak perusahaan belum menempatkan direksi independen (tidak terafiliasi) dalam susunan dewan direksinya, sehingga banyak perusahaan yang tidak dapat memenuhi kriteria sampel. Walaupun ada kewajiban untuk menempatkan 1 direksi independen tapi ternyata banyak perusahaan yang belum menginformasikan siapa direksi yang independen di perusahaan.

\section{SIMPULAN DAN SARAN \\ Simpulan}

Penelitian ini menguji kemungkinan perubahan strategi perusahaan berdasarkan hasil kinerja dan independensi dewan direksi. Independensi diukur dalam perbandingan antara komposisi direksi independen dibanding total seluruh direksi. Komposisi direksi independen diyakini dapat mempengaruhi kualitas keputusan dan kinerja. Pada saat perusahaan mengalami hasil kinerja yang buruk maka ada kemungkinan pergantian dewan direksi. Perusahaan akan mengganti direksi dengan direksi yang independen. Perubahan ini diyakini akan merubah strategi perusahaan. Hasil penelitian menunjukkan hubungan yang signifikan antara independensi dewan direksi dengan kinerja $\mathrm{ROE}(\mathrm{r}=0,311$, $\mathrm{p}=0,025)$ bahwa kinerja yang tinggi berhubungan dengan adanya independensi dewan direksi. Hasil untuk regresi logistik adalah bahwa prediksi tanda pada IND_BOD adalah sesuai bahwa keberadaan direksi independen menyebabkan perubahan strategi menjadi differentiation. Namun hal ini tidak signifikan secara statistik.

\section{Saran}

Penelitian ini memiliki keterbatasan karena hanya mencakup 3 bidang industri saja, yaitu manufaktur, perdagangan dan jasa. Penelitian berikutnya dapat memperluas cakupan sampel untuk seluruh perusahaan. Karakteristik negara Indonesia merupakan salah satu kelemahan utama penelitian ini. Indonesia adalah negara berkembang yang masih menerapkan strategi biaya rendah dalam proses produksinya sehingga penerapan strategi diferensiasi belum banyak diterapkan karena adanya kekurangan dalam bidang teknologi.

\section{DAFTAR PUSTAKA}

Beasley, M. S.,1996. "An Emperical Analysis of the Relation between the Board of Director Composition and Financial Statement Fraud." The Accounting Review, vol. 71 no.4 (Oct), pp: 443- 445

Gani, L., \& Jermias, J., 2006, "Investigating The Effect of Board Independence on 
Performance Across Different Strategies", The International Journal of Accounting, p. 295314

Helfert, E. A. 1991, Tecniques of Financial Analysis, Sevent Edition. Homewood Illinois : Richard D. Irwin Inc.

Hermalin, B. E., \& Weisbach, M., S., 1988, "The Determinants of Board Composition", Journal of Economics, Vol.19, No.4, p.589-606

Kosnik R. D, 1990, "Effect of Board Demography and Director Incentives on Corporate Greenmail Decisions”, Academy of Management Journal,

Ningrum, VDA., 14 Agustus 2015, Independensi dapat meningkatkan kepercayaan terhadap profesi akuntan public, diakses 20 September 2015,

www.jtanzilco.com/blog.detail/ 175/slug/independensi-dapatmeningkatkan-kepercayaan terhadap profesi-akuntanpublik

Pearce, John. A., Zahra, Shaker A., 1992, "Board Composition From A Strategic Contingency Perspective”, Journal of Management Studies

Porter M. E, 1994. Keunggulan Bersaing, Cetakan Pertama Binarupa Aksara Jakarta.

Robert M. G. 1997, Analisis Strategi Kontemporer. Konsep, Teknik, dan Aplikasi. Penerbit Erlangga. Jakarta.

Shivdasani, A. 1993. Board Composition , Ownership
Structure, and Hostile

Takeovers, Journal of Accounting and Economics Vol. 16, p.167-198

Stone, M., \& Rasp, J., 1991, "Tradeoffs in the Choice Between Logit and OLS for Accounting Choice Studies", The Accounting Review, vol. 66 no. 1, p. $170-187$

Wardani, R., 2006, Mekanisme Corporate Governance Dalam Perusahaan Yang Mengalami Permasalahan Keuangan (Financially Distres sed Firms), Paper dipresentasikan pada acara Simposium Nasional Akuntansi IX, Padang

Zahra, S. A.,Pearce, J. A., 1989, "Boards of Directors and Corporate Financial Performance : A Review and Integratetive model", Journal of Management 